PAEDAGOGIA ChristianA

I /23(2009) - ISSN 1505-6872

Jerzy Kostorz ${ }^{*}$

Opole

\title{
Sport w wychowaniu i ewangelizacji
}

Współczesny sport to jeden z największych fenomenów kulturowych XX i XXI wieku, obejmujący swym zasięgiem wszystkie kontynenty i narody świata, w który zaangażowane są potężne środki finansowe oraz miliardowe rzesze kibiców. Sport to fenomen mający charakter nie tylko pięknej karty w historii świata i człowieka, kształtujący nie tylko wielkie kulturowe i edukacyjne wartości, lecz również niosący z sobą różnego rodzaju obawy i zagrożenia. Wiąże się to z coraz częstszymi przypadkami degradacji uczestników sportu, które polegają na przedkładaniu takich wartości, jak: prestiż, medal, mistrzostwo, popularność, pieniądze itp., ponad wartość najwyższą - osobę (sportowca) ${ }^{1}$. W związku z tym rodzi się konieczność nieustannego przypominania o właściwym pojmowaniu sportu oraz jego miejscu w życiu człowieka, a co za tym idzie także jego roli w procesie wychowania i ewangelizacji.

Dla właściwej prezentacji powyższej problematyki najpierw zostanie podjęta próba określenia zjawiska sportu. Następnie ukazany zostanie sport w optyce etyczno-moralnej i tym samym wskaże się negatywy i pozytywy fenomenu sportu. W dalszej części zostaną ukazane niektóre możliwości wykorzystania sportu w procesie wychowania. Ostatni zaś punkt będzie próbą zarysowania sportu jako współczesnej formy ewangelizacji.

\section{Określenie zjawiska sportu}

Sport współcześnie jest bez wątpienia jedną z najpopularniejszych i najważniejszych dziedzin ludzkiego życia. Od samego początku człowiek doskonalił

* Ks. dr hab. Jerzy Kostorz - wykładowca katechetyki, pracuje na Wydziale Teologicznym Uniwersytetu Opolskiego, duszpasterz akademicki.

${ }^{1}$ Z. Dziubiński, Wstęp, w: tenże (red.), Edukacja poprzez sport, Warszawa 2004, s. 31-28. 
otaczającą go rzeczywistość, także w dziedzinie sportu. Dzięki coraz to doskonalszym i bardziej dostępnym środkom masowego przekazu stał się on zjawiskiem powszechnie znanym. Wydarzeniami sportowymi żyją współczesne społeczeństwa. Gdy jest on oparty na podstawowych założeniach humanistycznych oraz na ideałach olimpizmu starożytnej Grecji, gdzie agonistyka sportowa stanowiła integralną część systemu ówczesnego wychowania, może znacząco wpływać na kształtowanie osobowości człowieka².

Tak z historycznego, jak i z codziennego doświadczenia wiemy na ogól, czym jest sport, jaką odgrywa rolę i jaki jest jego cel w życiu ludzkim, jak funkcjonuje w świadomości społecznej, jakie pozytywne i negatywne zjawiska mu towarzyszą, na jakie wzloty i upadki jest narażony. Na zjawisko sportu można popatrzeć $\mathrm{z}$ bardzo wielu rozmaitych punktów widzenia: sportowca, trenera, kibica, lekarza, socjologa, psychologa, filozofa, etyka czy teologa ${ }^{3}$. By dokonać pogłębionej refleksji dotyczącej roli sportu w procesie wychowania i ewangelizacji, należy najpierw jednoznacznie określić treść, sens, znaczenie pojęcia „sport”, czyli ustalić, co nim jest, a co nim nie jest.

Słowo „sport” wywodzi się z łacińskiego pojęcia disporto oraz disporte i składa się z rzeczownika porta czyli brama oraz przedimka dis, wyrażającego wyjście poza miasto w celu zażycia świeżego powietrza, ruchu i przyjemności. W ten sposób ukształtowało się słowo disporte, które nie posiada precyzyjnego odpowiednika w języku polskim, a oznacza zaprzestanie czynności powszednich w celu oddania się rozrywce i wypoczynkowi. Można zatem powiedzieć, iż na gruncie takiego określenia posiada on wymiar święta czy świętowania ${ }^{4}$.

Od samego początku sport posiadał wiele znaczeń i określeń. Dokonując jego charakterystyki, zwraca się najczęściej uwagę na to, iż jest to działalność uprawiana systematycznie, według pewnych reguł, odznaczająca się wyraźnym pierwiastkiem współzawodnictwa oraz tendencją do osiagania coraz lepszych wyników, mająca na celu manifestację sprawności ruchowej. Podstawę klasyfikacji sportu stanowi rodzaj walki sportowej: z przeciwnikiem, przestrzenią, czasem lub o punkty ${ }^{5}$. Zasadniczo można wyróżnić sport amatorski i zawodowy. Pierwszy rodzaj ma charakter uczestnictwa w sporcie bez korzyści materialnych, drugi natomiast wiąże się z uczestnictwem nastawionym na takie korzyści ${ }^{6}$.

Wśród różnych interpretacji zjawiska sportu na czoło wysuwa się jego związek z kulturą. Interpretację tę nazywa się antropologiczno-kulturową. Przedstawi-

${ }^{2}$ Por. J. Niewęgłowski, Wiara a sport. Rola wychowania, w: Z. Dziubiński (red.), Wiara a sport, Warszawa 1999, s. 238.

${ }^{3}$ M. Mylik, Czy sportowiec może zostać świętym?, w: Z. Dziubiński (red.), Wiara a sport, s. 171.

${ }^{4}$ Z. Dziubiński, Wstęp, s. 31.

${ }^{5}$ Tamże.

${ }^{6}$ Por. J. M. Cygan, Teologia sportu w perspektywie myśli katolickiej, w: Z. Dziubiński (red.), Chrześcijańska etyka sportu, Warszawa 1993, s. 9; G. Milanesi, Sport a społeczeństwo, w: Z. Dziubiński (red.), Wychowawcze aspekty sportu, Warszawa 1993, s. 13-17. 
ciele takiego rozumienia sportu pojmują go jako strukturę społeczno-kulturową i umieszczają w kategoriach wartości i wzorów kultury, które z kolei mają istotny wpływ na typy osobowości. Na tym gruncie można wyodrębnić trzy sfery sportu: kultury bytu, kultury społecznej, kultury symbolicznej. Do pierwszej należą materialne obiekty i urządzenia, dzięki którym mogą być realizowane różnorodne cele i zadania sportowe (stadiony, boiska, hale, pływalnie, lodowiska, skocznie, aparatura pomiarowa itp.). Druga sfera wiąże się z celem aktywności sportowej, która tutaj jest związana wyłącznie z efektami fizycznymi, czyli z bezpośrednią poprawą zdrowia fizycznego i psychicznego, sprawnością i wydolnością fizyczną (np. przygotowanie do pracy zawodowej, obronnej). W niej aktywność sportowa pełni funkcję instrumentalną. Trzecia sfera nawiązuje do pojmowania sportu jako dziedziny kultury, w której największą rolę odgrywają wartości symboliczne. Sprawność i wydolność fizyczna, zdrowie są w tej sferze narzędziami do osiągania takich wartości symbolicznych jak: rywalizacja, walka, osobisty sukces, znoszenie porażki, a także przyjaźń, pokój, napięcia i konflikty, współpraca i koegzystencja?.

Ważną w całokształcie podjętej problematyki wydaje się klasyfikacja sportu ze względu na kryterium motywacyjne, czyli na intencje, jakie przyświecają uprawianiu go. Według H. Grabowskiego zjawisko sportu może występować jako:

- widowisko - sport pasywny (kibicowanie, które jednak nie stanowi ani koniecznego, ani też wystarczającego warunku uczestnictwa w sporcie);

- środek realizacji pozasportowych celów (sport instrumentalny). W tym przypadku aktywność ruchowa stanowi instrument osiagania pozasportowych celów i wartości (hedonistycznych, utylitarnych, zdrowotnych i wychowawczych);

- autoteliczny czyli posiadający wartość samą w sobie. Uczestnictwo w sporcie wynika tu z odwiecznych dążeń agonistycznych i perfekcjonistycznych, a celem jest samorealizacja na drodze współzawodnictwa w dążeniu do osiagnięcia optymalnych rezultatów w zakresie sprawności fizycznej i ruchowej ${ }^{8}$.

Wieloaspektowość sportu jest potwierdzeniem jego naczelnego miejsca w życiu człowieka, społeczeństw i narodów. Wszelakie możliwości doskonalenia sportowego wskazują również na jego sens i cel w życiu ludzkim. Najważniejszym celem sportu jest jak najlepsze usprawnienie naturalnego, pierwotnego popędu do walki z trudnościami w celu zniszczenia, złagodzenia lub odrzucenia zła zagrażającego człowiekowi. Tak pojęty cel sportu jest nie tylko nadrzędny wobec innych celów, ale konieczny w normalnym, naturalnym rozwoju i funkcjonowaniu każdego człowieka9. Potwierdzenie takiego rozumienia celowości zjawiska sportu odnajdujemy w metafizycznych poglądach św. Tomasza z Akwinu, na

\footnotetext{
${ }^{7}$ Tamże, s. 37.

${ }^{8}$ H. Grabowski, Teoria fizycznej edukacji, Warszawa 1999, s. 41-44.

${ }^{9}$ M. Mylik, dz. cyt., s. 186-188.
} 
podstawie których można ująć „sport jako stricte ludzką przypadłość, pewnego rodzaju sprawność (łac. habitus), rozumianą jako zespół czynności typowo ludzkich wynikających z samych pierwocin natury ludzkiej, uporządkowanych przez rozum i skierowanych przez wolę, czasem nawet z wydatną pomocą uczuć, do określonego celu zgodnego z natura człowieka (popęd do walki)" ${ }^{10}$. Św. Tomasz wręcz zachęca, aby ze sportu uczynić narzędzie działania cnoty ${ }^{11}$. Poglądy św. Tomasza są w pewnym sensie potwierdzeniem dość powszechnej tezy, iż ostatecznym i podstawowym uzasadnieniem konieczności fizycznego usprawniania ciała i ducha poprzez sport dla wszystkich przedstawicieli nauk szczegółowych czy humanistycznych, zajmujących się tym fenomenem, jest nade wszystko filozoficzna istota i teologiczne aspekty sportu.

\section{Sport w ocenie moralnej}

Pytaniem zasadniczym, które należałoby w tym miejscu postawić, jest pytanie: dlaczego etyka sportu? Odpowiedź na nie wiąże się ściśle z potrzebą etycznej odpowiedzialności w każdej dziedzinie ludzkiego życia. Współczesny sport wyczynowy należy do specyficznych zawodów wykonywanych przez człowieka. W odniesieniu do społeczności sportowej mamy do czynienia z jakościowo i wartościowo różnymi „usługami społecznymi”. Działania posiadające charakter: walki, zmagania, rywalizacji, wysiłku zaliczane są do tzw. „usług społecznych", chociaż w innym wymiarze niż usługi produkcyjne. Takie jednak rozumienie wykonywanego zawodu rzutuje na specyficzną strukturę wewnętrzną społeczności sportowej, a to w konsekwencji wymaga specyficznych regulacji etycznych ${ }^{12}$.

Ocena moralna w sporcie powinna spełniać określone funkcje. W pierwszej kolejności chodzi o normy i zasady etyczne, których zadaniem jest regulowanie wewnętrznych stosunków ludzi sportu. Kolejny wymiar powinien określać stosunek sportowców do „przedmiotu” ich działania. Następny zaś powinien stanowić formę zabezpieczenia przed zagrożeniami moralnymi ${ }^{13}$. Przyjrzenie się zjawisku sportu w optyce etyczno-moralnej, tak od strony zagrożeń i nadużyć, jak od strony pozytywnych wartości będzie potwierdzeniem konieczności zasad i norm moralnych w tej powszechnej dziedzinie ludzkiego życia, które powinny dotyczyć trzech zasadniczych płaszczyzn; sfery przekonań etycznych, opartych

${ }^{10}$ Cyt. za: M. Mylik, dz. cyt., s. 174.

${ }^{11}$ Cyt. za: A. Andrzejuk, Sport i modlitwa, w: Z. Dziubiński (red.), Teologia i filozofia sportu, Warszawa 1997, s. 239; por. tenże, Sport w ujęciu tomistycznym, w: Z. Dziubiński (red.), Kościót a sport, Warszawa 1995, s. 47-61.

${ }^{12}$ H. Skorowski, Wokót etyki sportu, w: Z. Dziubiński (red.), Sport na przełomie tysiqcleci: szanse i nadzieje, Warszawa 2000, s. 224-225.

${ }^{13}$ Tamże. 
na uznanych za powszechne w środowisku sportowym wartościach moralnych; sfery kategorycznych powinności moralnych oraz sfery postaw moralnych ${ }^{14}$.

\subsection{Negatywne oblicze sportu}

Sport jest dziś dla wielu bogiem, sacrum, religią. O wiele częściej mówi się dziś ,sport to mord” zamiast ,sport to zdrowie”. W literaturze przedmiotu spotykamy wiele stanowisk, z punktu widzenia których bilans pozytywów i negatywów w sporcie jest ujemny. Z. Krawczyk stwierdza, że współczesny sport wyczynowy w ogromnie szybkim tempie przejawia skłonność do przeobrażenia się we własne przeciwieństwo, i to zarówno co do swej istoty, jak również funkcji biologicznej, społecznej i kulturowej. Bardzo powszechne są dziś w sporcie takie patologiczne zjawiska jak: stosowanie niedozwolonych środków farmakologicznych, manipulowanie ludzkim życiem (np. stosowanie dopingu ciążowego w celu uzyskania optymalnej wydolności organizmu), dawkowanie nadmiernych obciążeń treningowych, przedkładanie celów komercyjnych nad cele osobowe, szowinizm, nacjonalizm, brutalizacja zachowań itp ${ }^{15}$. Złą kondycję moralną współczesnego sportu wyrażał niejednokrotnie Jan Paweł II.

Dość liczne niestety i być może coraz bardziej widoczne są oznaki kryzysu, który zagraża fundamentalnym wartościom etycznym sportu. Obok sportu, który pomaga człowiekowi, istnieje sport inny, który mu szkodzi; obok sportu, który uszlachetnia ciało, istnieje sport, który je poniża i zdradza; obok sportu, który służy wzniosłym ideałom, jest też sport, który zabiega wyłącznie o zysk; obok sportu, który jednoczy, jest też taki, który dzieli ${ }^{16}$.

U podstaw upowszechniających się coraz bardziej patologicznych zachowań w sporcie leży zjawisko lekceważenia starożytnych i nowożytnych zasad antropologii olimpijskiej, zalecających harmonijny rozwój ciała i ducha ${ }^{17}$. W konsekwencji pojawia się tutaj groźba deformacji i degradacji osobowości, nie tylko w przypadku sportowców kontuzjowanych, lecz także w przypadku tych, których namawia się do postępowania amoralnego i nieetycznego. Żyją oni bowiem w świecie wewnętrznie sprzecznym, opartym na ambiwalentnej strukturze aksjologicznej, wykluczającej się ze skali wartości. Z jednej strony próbują zachować reguły powszechnie obowiązujące, z drugiej zaś podważają je ze względu na rozmaite społeczne oczekiwania i własne korzyści. Gotowi są na jednej szali

14 Tamże, s. 226.

${ }^{15}$ Z. Dziubiński, Kościół katolicki wobec współczesnego sportu wyczynowego, w: tenże (red.), Sacrum a sport, Warszawa 1996, s. 58-60.

${ }^{16}$ Jan Paweł II, Oblicze i dusza sportu, „L'Osservatore Romano” 22 (2001), nr 1, s. 19.

${ }^{17}$ Z. Dziubiński, Wiara - wychowanie - sport, w: tenże (red.), Wiara a sport, s. 251-252. 
postawić sukces, a na drugiej swoje zdrowie i zdrowie rywala. Świadectwem potwierdzającym upadek humanistycznych wartości sportu, jego olimpijskich i rycerskich korzeni, są dziś naturalne w szkoleniu tzw. faule taktyczne, agresja na boisku, zastraszanie rywala przed i w trakcie trwania zawodów ${ }^{18}$.

Sport stał się dziś intratnym biznesem. Komercjalizacja zawodów sportowych prowadzi do takich praktyk jak kupowanie wyników, kaperownictwo, instrumentalne traktowanie zawodników, sprowadzanie sportu do roli towaru podlegającego prawu podaży i popytu. Deformacja sportu wynika także z jego upolitycznienia, co w efekcie prowadzi do etnicznego szowinizmu wyzwalającego wrogą postawę wobec obcych, zagranicznych drużyn sportowych. Dostrzegamy także psychologiczne powody odejścia od ideałów sportu, co ma wyraz w coraz bardziej ostrej i często brutalnej grze zawodników na stadionie. Towarzyszą temu bijatyki pseudokibiców. Gra sportowa zatraca swój humanistyczno-perfekcjonistyczny profil, przeistaczając się w gladiatorstwo ${ }^{19}$.

Szczególnym zagrożeniem współczesnego sportu jest częste stosowanie dopingu, czyli różnych środków farmakologicznych wspomagających siły fizyczne zawodników, co w konsekwencji ma wpływać na uzyskanie przewagi nad rywalami w grze sportowej. Doping jest zagrożeniem zdrowia, a często także życia nieuczciwych sportowców. Choć prawnie jest zakazany, to jednak w praktyce sportowej często stosowany i tolerowany przez wielu lekarzy oraz trenerów i traktowany jako efektywny środek zapewniający zwycięstwo w bezwzględnej rywalizacji. Szczególnie niepokojącym zjawiskiem jest podawanie zakazanych środków dopingujących dzieciom i młodzieży, często nieświadomym ich negatywnych skutków. Ponadto coraz częściej zaczynają „,szpikować się” dopingiem osoby uprawiające sport amatorsko, w przekonaniu, iż to ułatwi im powiększanie masy mięśniowej i przyspieszy uzyskanie sportowej sylwetki ${ }^{20}$.

Nie ulega wątpliwości, że sport na najwyższym poziomie przynosi ogromne zyski nie tylko zawodnikom i trenerom, ale również organizatorom imprez, producentom sprzętu itp. Na tym gruncie szczególnie szkodliwe jest zjawisko korupcji oraz kaperownictwo. Korupcja ma tutaj charakter przekupywania sędziów, trenerów i sportowców. Dotyka ona również członków Międzynarodowego Komitetu Olimpijskiego w związku ze staraniami różnych miast i państw o organizację igrzysk olimpijskich ${ }^{21}$.

Kaperownictwo czyli kupowanie, przekupywanie w sporcie, szczególnie dotkliwie uderza w dzieci i młodzież. Osoby trudniące się tym procederem traktują sportowca w sposób wyłącznie instrumentalny, nie zważając na potrzeby edu-

${ }^{18}$ J. Kosiewicz, Wspótczesny olimpizm w świetle wartości społecznych, w: Z. Dziubiński (red.), Aksjologia sportu, Warszawa 2001, s.189-190.

${ }^{19}$ S. Kowalczyk, Sport w świetle personalistycznej koncepcji kultury, w: Z. Dziubiński (red.), Sport jako kulturowa rzeczywistość, Warszawa 2005, s. 53-54.

${ }^{20}$ J. Kosiewicz, dz. cyt., s. 190-191.

${ }^{21}$ Tamże, s. 191. 
kacyjne czy wychowawcze ${ }^{22}$. Za pieniądze można dziś kupić w świecie sportu każdego i wszystko. Cena uzdolnionych sportowców sięga dziś kilkudziesięciu milionów euro a ich zarobki są równie wysokie. Dla przykładu zarobki najlepiej zarabiających piłkarzy kształtują się następująco: David Beckham - 24,5 mln euro; Ronaldinho - $24 \mathrm{mln}$ euro; Ronaldo 15,5 $\mathrm{mln}$ itd $^{23}$.

Takie traktowanie sportu w efekcie grozi wypaczeniem relacji sportowych, podważeniem olimpijskich i humanistycznych idei i wartości oraz zachwianiem właściwych postaw moralnych w sporcie. Szczególną rolę w sensie profilaktycznym i terapeutycznym może odegrać wychowanie olimpijskie jako integralny składnik kompleksowego procesu wychowawczego ${ }^{24}$.

\subsection{Pozytywne oblicze sportu}

Pozytywna rola sportu uzależniona jest od wielu czynników, między innymi nastawienia samego sportowca, formacji i zdolności pedagogicznych bezpośrednich opiekunów, trenerów, charakteru realizowanego programu szkolenia sportowego, bezwarunkowego przestrzegania obowiązujących zasad. Sport bardzo precyzyjnie ukazuje walkę człowieka ze swoimi słabościami, oporem materii, uczy przekraczania barier, pomaga w lepszym poznaniu siebie, stwarza autokreacyjne możliwości, daje szansę realizowania się osoby. Na gruncie właściwego pojmowania sportu, jego uczestnik w sposób świadomy i całkowicie dobrowolny poddaje się reżimowi treningowemu i zgadza się na respektowanie reguł obowiązujących w sporcie ${ }^{25}$.

Aksjologiczna analiza fenomenu sportu pozwala na uchwycenie jego natury jako źródła i nośnika wartości. Sport, jak każda działalność ludzka, jest wyposażony w intencje wprost lub pośrednio nawiązujące do wartości, stanowiąc z jednej strony specyficzną formę realizacji zastanych reguł, wzorców i ideałów, a z drugiej, jest miejscem i sposobem tworzenia wartości nowych pretendujących do przyszłej trwałości i cechujących się niezwykłą niepowtarzalnością (wartości estetyczne czy swoista dramaturgia) ${ }^{26}$.

Oprócz roli służebnej sport jest generatorem i manifestacją wartości oryginalnej i autotelicznej zarazem, a jest nią bezinteresowna sprawdzalność ludzkiej mocy życiowej. Niezależnie od tego, czy czemuś czy komuś służy, czyli jest instrumentalny wobec innych wartości, sport wyznacza swoją własną dziedzinę w aksjo-

${ }^{22}$ Tamże; S. Kowalczyk, dz. cyt., s. 53-54.

${ }^{23}$ M. Czechowicz, T. Lipiński, L. Orłowski, 25 najlepiej zarabiajacych piłkarzy świata, „Piłka Nożna Plus" 263 (2007), nr 11, s. 6-10.

${ }^{24}$ J. Kosiewicz, dz. cyt., s. 192; por. K. Zuchowa, Olimpizm - wartości edukacyjne, w: Z. Dziubiński (red.), Wychowawcze aspekty, s. 67-80.

${ }^{25}$ Z. Dziubiński, Kościół katolicki, s. 60-61.

${ }^{26}$ J. Lipiec, Sport jako wartość w kręgu aksjologii esencjalnej, w: Z. Dziubiński (red.), Aksjologia, s. 176-178. 
sferze. Z tej perspektywy zjawisko sportu wyzwala i urzeczywistnia samodzielną wartość złożoną. To, co jest „dla dobra” w sporcie - kształtuje sferę wartości moralnych; to, co „dla piękna” - tworzy świat wartości estetycznych; to, co „dla prawdy” - określa wartości poznawcze; to, co „dla wygody i sprawności” - leży u podstaw wartości utylitarnych i pragmatycznych. W takim rozumieniu wartość sportu posiada charakter autoteliczny (samocelowy i nieinstrumentalny) ${ }^{27}$.

Ukonkretnieniem pozytywnego oblicza sportu na gruncie oceny moralnej jest wspomniana już wcześniej idea olimpizmu, która jest wspaniałą „,warzą sportu”. Do jej zwolenników należy liczna grupa humanistycznie zorientowanych teoretyków tego zjawiska, którzy znając dobrze słabości i zagrożenia sportu, dostrzegają w nim wiele pozytywów i chcą z niego uczynić obszar realizacji najwznioślejszych wartości ludzkich i płaszczyznę potęgowania człowieczeństwa. Na miano nowożytnego prekursora, odkrywcę na nowo idei i zasad olimpizmu, zasłużył baron P. de Coubertin (1863-1937; MKOL 1896). Ten „,apostoł sportu i laicki teolog" dostrzegał w sporcie szansę reformy wychowania i wykształcenia młodzieży. Coubertinowski olimpizm w kręgu swych wartości sytuuje wolność, godność, wzajemny szacunek i poszanowanie norm. W sporcie odkrywa zarówno wartości cielesne, jak i duchowe, ponieważ dopiero z ich harmonii może zrodzić się szlachectwo, które powinno dać początek ładowi nowego świata zorganizowanego na wzór globalnej wioski olimpijskiej. Sport zatem powinien być impulsem i inspiracją do budowy nowego świata, opartego na poszanowaniu godności człowieka ${ }^{28}$ oraz promowoać ideę fair play, pokój, solidarność, koleżeństwo oraz zdyscyplinowanie i poszanowanie przepisów, co w efekcie wpływa na jakość życia ${ }^{29}$.

Idea olimpizmu jest zatem dobrym i skutecznym narzędziem, dzięki któremu można przywrócić właściwe oblicze i właściwą wartość zjawisku sportu. Praktycznym zaś odzwierciedleniem wartości sportu jest jego rola i udział w procesach wychowania i ewangelizacji.

\section{Znaczenie sportu w procesie wychowania}

Współczesny sport w humanistycznej wersji odwołujący się do zasad olimpizmu wchodzi w rozliczne związki z pedagogika, psychologią, etyką, literatura, sztuką oraz odwołuje się do najgłębszych przeżyć duchowych. Głosząc hasła pokoju, wolności, tolerancji, solidarności, przyjaźni, szacunku, poszanowania godności, wszechstronnego rozwoju człowieka, a równocześnie przeciwstawiając się wojnie, przemocy, rasizmowi, nacjonalizmowi, wszelkiej dyskryminacji staje się swoistego rodzaju wzorcem pedagogicznego i moralnego postępowania. Pedago-

27 Tamże, s. 177.

${ }^{28}$ Z. Dziubiński, Kościót katolicki, s. 61-62.

${ }^{29}$ E. Kałamacka, Sport XXI wieku epigonem antyku, w: Z. Dziubiński (red.), Sport na przełomie tysiacleci, s. 156-157. 
giczne znaczenie sportu wyraźnie akcentują takie dokumenty Rady Europy, jak: Europejska Karta Sportu, Kodeks Etyki Sportowej, Deklaracja w sprawie sportu, tolerancji i fair play. W tym ostatnim dokumencie czytamy: „sport oferuje społeczeństwu ogromny potencjał stanowiący podstawę zetknięcia się ze sobą kultur, tworzy klimat wzajemnego zrozumienia, szacunku i tolerancji, stanowi obraz socjalizacji i integracji, jest szkołą demokracji, ważnym elementem wychowania, szczególnie ludzi młodych"30.

Edukacja poprzez sport oznacza zarówno proces kształcenia, jak i wychowania w sporcie i dla sportu, ale także poprzez sport do życia społecznego w ogóle, do kultur, do życia w nowej Europie, do globalizacji świata, do tolerancji. Oznacza to, iż wychowanie poprzez sport powinno realizować nie tylko cele czysto sportowe, lecz także pozasportowe, wierząc, że doznania poznawcze i emocjonalne, nabyta wiedza, umiejętności, nawyki, doświadczenia i przekonania będą przenoszone na inne obszary życia społecznego. Istotną rolę w nadawaniu edukacyjnego wymiaru sportowi odgrywają nauczyciele, wychowawcy, trenerzy, animatorzy sportowi, od których zależy czy będą potrafili wykorzystać sport jako narzędzie realizacji wymienionych wartości i ideałów. Sport jest bowiem potencjalnie dobry, ale jego prawdziwa wartość ujawnia się dopiero w kulturowej praktyce ${ }^{31}$.

W procesie wychowania sport może być traktowany dwojako. Po pierwsze, jako środek wychowania i wówczas mamy do czynienia ze zjawiskiem wychowania przez sport. Po drugie, zaś jako cel wychowania i wtedy mamy do czynienia $\mathrm{z}$ wychowaniem do sportu, a sport ma charakter społeczno-kulturowy ${ }^{32}$.

Wychowanie przez sport, dzięki któremu wpływamy na rozwój osobowości, może przybierać różne wymiary. To między innymi wychowanie do zwycięstwa, porażki, bezinteresowności, zasady fair play ${ }^{33}$.

Wychowanie do zwycięstwa to jedno z najtrudniejszych zadań, jakie stoi przed współczesnym pedagogiem ${ }^{34}$. Współzawodnictwo i rywalizacja należą do istoty sportu od samego początku. Każdy uprawiający sport ma na celu zdobycie głównej nagrody, medalu czy poprawienie aktualnego rekordu. To współzawodnictwo staje się bodźcem działania dla sportowca. Aby tak było w rzeczywistości należy wyeliminować niebezpieczeństwo traktowania sportu jedynie jako gry przeciw drugiej osobie (za wszelką cenę!). Gra bowiem ma mieć charakter spotkania osób, a nie walki z osobami. Zwycięzca to ten, który wypada najlepiej wobec próby, jaką jest konkretna gra. To też powinno być elementem decydującym, a nie zwycięstwo nad rywalem. W sytuacji zwycięstwa sportowiec musi być świadomy, że na jego sukces złożyła się praca i wysiłek wielu osób, czyli drużyny, trenerów, obsługi technicznej,

${ }^{30}$ Cyt. za: Z. Dziubiński, Wiara - wychowanie - sport, s. 250.

${ }^{31}$ Z. Dziubiński, Wstęp, s. 41.

32 J. Nowocień, Sport w opinii uczestników Parafiady 94, w: Z. Dziubiński (red.), Kościót a sport, s. 314.

${ }^{33}$ J. Niewęgłowski, Sport i wychowanie, w: Z. Dziubiński (red.), Teologia, s. 252.

${ }^{34}$ Tamże. 
medycznej itp. Zwycięstwo to również umiejętność dostrzeżenia pokonanych przeciwników. Istotnym momentem wychowawczym jest kształtowanie postawy wyrażającej się w podejściu do pokonanego, podaniu mu ręki, podziękowaniu za grę i wypowiedzeniu słów pocieszenia. Wychowanie powinno uświadomić sportowcom, iż ludzką rzeczą jest zwyciężać i taką samą rzeczą jest przegrywać. Wychowanie do takiej postawy jest $\mathrm{w}$ dzisiejszym świecie zadaniem bardzo trudnym ${ }^{35}$.

Wychowanie do porażki powinno być obecne w każdym stylu i typie wychowania. Jest to zazwyczaj proces długotrwały. Umiejętność przyjęcia lub odrzucenia porażki wiele mówi o danej osobie, o jej równowadze emocjonalnej i osobowości. Proces wychowania do przyjęcia porażki jest czasem bardzo długotrwały. By niepowodzenie było właściwie zaakceptowane i przyjęte wymaga odpowiednio ukształtowanej hierarchii wartości. Porażka winna pomagać w odkrywaniu braku formy, słabego przygotowania czy posiadania mało skutecznej taktyki. Tak pojmowana stanowi ona dobrą okazję do sprawdzenia samego siebie i własnej osobowości. Wychowanie do porażki winno uwalniać od traktowania sportu jako czynności czysto technicznej i nastawionej wyłącznie na rezultaty oraz kształtować świadomość, że zwycięzcy to ludzie, a nie moi wrogowie, którzy podczas zawodów wykazali lepszą formę, taktykę i większe umiejętności ${ }^{36}$.

$\mathrm{W}$ czasach, kiedy wiele inicjatyw sportowych organizowanych jest w celach wyłącznie komercyjnych, bardzo potrzebne wydaje się wychowanie do bezinteresowności. Wychowanie to powinno pomagać sportowcom w rezygnacji z takich sytuacji, w których wszystko jest wyłącznie handlem, gdzie za wszystko się płaci i wszystko kupuje. W świetle wartości bezinteresowności sport nie będzie jedynie miejscem walki na wszelką cenę, ale również miejscem rozrywki, zabawy i świętowania. To wychowanie powinno wyrabiać również postawę pozbawioną agresji i przemocy. W przypadku zaś kibiców wychowanie do bezinteresowności winno kształtować właściwą postawę w stosunku do zwycięskiej drużyny i jej zwolenników, tak aby w konsekwencji sport był doświadczeniem radości, święta i twórczości ${ }^{37}$.

Wśród sportowców postuluje się przestrzeganie nie tylko pisanych, ale i niepisanych reguł etycznych, które wypływają z ducha prawa. Zasada fair play w praktyce oznacza uczciwą i czystą rywalizację sportowa, która przebiega według odpowiednio ustalonych reguł gry. Istotą właściwego wychowania do zasady fair play jest respektowanie następujących zasad moralnych: zasady przestrzegania wszystkich reguł gry; zasady podporządkowania się wszystkim decyzjom sędziego, który z kolei powinien być bezstronny wobec dwóch stron; zasady zachowania równych szans; zasady świadomej rezygnacji z osiagnięcia zwycięstwa w sposób nieuczciwy.

${ }^{35}$ Tenże, Kultura - sport - wychowanie, w: Z. Dziubiński (red.), Sport na przełomie tysiacleci, s. 252.

${ }^{36}$ A. Andrzejuk, Sport i modlitwa, s. 253-254.

${ }^{37}$ Tamże, s. 254. 
Wychowanie do tej zasady oznacza ukształtowanie w człowieku takiej postawy moralnej, która wyklucza możliwość zwycięstwa za wszelką cenę. Ważne jest nie samo zwycięstwo, ale sposób w jaki zostało osiągnięte. Zasada fair play pomaga sportowcom przejść $\mathrm{z}$ dyrektyw skuteczności rywalizacji na płaszczyznę dyrektyw moralnych, co w konsekwencji buduje świadomość godności własnej osoby i godności osoby przeciwnika. Postawa ta cechuje się bezinteresowną pomoca, wielkoduszną rezygnacją z dóbr materialnych, perfekcjonizmem, rzetelnością i umiejętnością rezygnacji z niezasłużonego zwycięstwa oraz poszanowaniem przeciwnika ${ }^{38}$.

Sport może być również bardzo skutecznym narzędziem w kształtowaniu cnót kardynalnych, czyli wychowaniu do postawy roztropności, sprawiedliwości, męstwa i umiarkowania. Uprawianie sportu ze swej natury domaga się roztropności, ponieważ trzeba w nim dokonywać wyboru poprawnych środków i pozostawać dojrzałym i wiernym w ich realizowaniu. Poprzez wytrwałe, wyczerpujące treningi sportowiec uczy się dysponowania swoją energią tak aby w odpowiedni sposób ją wykorzystać. W przypadku braku roztropności pojawia się niebezpieczeństwo utraty zdrowia czy nawet śmierci. Przy uprawianiu sportu nie można zapomnieć, że chodzi o takie usprawnienie człowieka, aby ani sobie ani innym nie zaszkodzić pod względem zdrowia, dobrej sławy i życia rodzinnego, lecz sumiennie spełniać wszystkie obowiązki, przestrzegając prawdomówności, szczerości, karności, posłuszeństwa, wdzięczności, czyli jednym słowem sprawiedliwości. Cnota sprawiedliwości musi także być obecna w samym sposobie osiagania wyników sportowych. Jednym z głównych zadań sportu jest kształtowanie postawy męstwa, czyli pomoc człowiekowi w usprawnianiu wrodzonego popędu do walki przez opanowanie związanych z nim uczuć, a zwłaszcza odwagi, bojaźni i szlachetnej ambicji, tak by wytrwale i cierpliwie spełniał swoje obowiązki mimo największych trudności i przeszkód. Z męstwem wiążą się inne cnoty, takie jak stałość, cierpliwość czy wielkoduszność. Niemalże wszystkie dyscypliny sportowe posiadają duże znaczenie w kształtowaniu postawy umiaru. Wzmacniają one bowiem kontrolę duchową nad ciałem i jego potrzebami, tak jak np. przestrzeganie odpowiedniej diety. To zaś wymaga niejednokrotnie wielu wyrzeczeń ${ }^{39}$.

Zaprezentowane wymiary oddziaływań wychowawczych poprzez sport z pewnością nie wyczerpują wszystkich możliwości oddziaływań pedagogicznych, ale są potwierdzeniem tezy, iż sport właściwie rozumiany i pokierowany może współcześnie być bardzo skutecznym narzędziem wychowawczym.

${ }^{38}$ J. Niewęgłowski, Kultura - sport-wychowanie, s. 252-253; por. Z. Żukowska, R. Żukowski, Nasze rozmowy z młodzieża o postawach fair play $w$ sporcie $i w \dot{z} y c i u, \mathrm{w}: \mathrm{Z}$. Dziubiński (red.), Drogi i bezdroża sportu i turystyki, Warszawa 2007, s. 342-353.

${ }^{39}$ M. Graczyk, Udziat sportu w kształtowaniu moralnych doskonałości człowieka, w: Z. Dziubiński (red.), Kościót a sport, s. 80-89; por. A. Andrzejuk, Sport w ujęciu tomistycznym, s. 53-57. 


\section{Sport jako narzędzie ewangelizacji}

Miarą żywotności Kościoła jest nieustanne poszukiwanie takich „narzędzi”, dzięki którym będzie on mógł skutecznie docierać z Ewangelią do ludzi. Jednym $\mathrm{z}$ nich jest sport. Potwierdzenie jego roli w procesie ewangelizacji odnajdujemy w sposób bezpośredni i pośredni w wielu dokumentach Kościoła.

Sport, mimo iż współcześnie określa się go mianem narzędzia nowej ewangelizacji, nie jest bynajmniej czymś nowym i nieznanym w strategii duszpasterskiej Kościoła. Już bowiem w Nowym Testamencie, w liście św. Pawła Apostoła do Koryntian czytamy:

Czyż nie wiecie, że gdy zawodnicy biegną na stadionie, wszyscy wprawdzie biegna, lecz tylko jeden otrzymuje nagrodę? Przeto tak biegnijcie, abyście ją otrzymali. Każdy, który staje do zapasów wszystkiego sobie odmawia; oni, aby zdobyć przemijającą nagrodę, my zaś nieprzemijającą. Ja przeto biegnę nie jakby na oślep, walczę nie tak, jakbym zadawał ciosy w próżnię, lecz poskramiam moje ciało i biorę je w niewolę, abym innym głosząc naukę, sam przypadkiem nie został uznany za niezdatnego (1 Kor 9, 24-27).

Św. Paweł za pomocą metafory zdrowego współzawodnictwa sportowego rzuca światło na wartość życia, przyrównując je do biegu ku celowi nie tylko ziemskiemu, ale również wiekuistemu, biegu, w którym nie tylko jeden zawodnik, ale wszyscy mogą być zwycięzcami ${ }^{40}$. Podobną myśl wyraził w II wieku po Chrystusie św. Ignacy, który strofując innego świętego - Polikarpa, pisał: „Spotęguj tempo Twojego biegu, bądź jak prawdziwy atleta, bo tam gdzie większy trud, tam też większa nagroda. Ćwicz się tedy w czujności jako atleta Boży"41. Już tu zatem dostrzegamy wykorzystanie wydarzeń sportowych jako tzw. „ewangelizacyjnych obrazów".

W Deklaracji o Wychowaniu Chrześcijańskim Soboru Watykańskiego II czytamy, iż Kościół wypełniając swój wychowawczy obowiązek sięga po różne środki pomocnicze, które służą duchowemu kształtowaniu człowieka, a do których zaliczyć można między innymi środki masowego przekazu oraz rozmaite zrzeszenia zajmujące się rozwojem duchowym i fizycznym (DWCH 3). Z kolei w Konstytucji duszpasterskiej o Kościele w świecie wspótczesnym jest mowa o potrzebie wolnego czasu, który powinien służyć odprężeniu duchowe$\mathrm{mu}$, wzmocnieniu zdrowia psychicznego i fizycznego, co jest możliwe także dzięki ćwiczeniom i pokazom sportowym (KDK 61) ${ }^{42}$. W 2004 roku na polece-

${ }^{40}$ M. Mylik, dz. cyt., s. 167.

${ }^{41}$ Tamże.

${ }^{42}$ T. Kukułowicz, R. Wysoczańska, Kościót wobec sportu, w: Z. Dziubiński (red.), Wiara a sport, s. 97-98. 
nie Jana Pawła II utworzono w jednym z departamentów watykańskich sekcję sportu, aby w ten sposób potwierdzić ważną rolę sportu we współczesnym świecie. W specjalnym oświadczeniu Watykanu stwierdzono, iż sport zajmuje dzisiaj znaczącą pozycję zarówno na poziomie osobistym, jak i globalnym. Stanowi niejako system nerwowy współczesnego świata i jest nowym polem działania dla Kościoła. Kościół, który zawsze interesował się ważnymi aspektami ludzkiej koegzystencji, musi również zwrócić się ku sportowi, który jest polem dla nowej ewangelizacji ${ }^{43}$.

Niezwykłe bogactwo sportu i jego pedagogiczne oraz ewangelizacyjne rozumienie wnosi w nauczanie Kościoła pontyfikat Jana Pawła II. Papież zdawał sobie doskonale sprawę z tego, że sport to wielki fenomen kultury społecznej, w którym uczestniczą prawie wszyscy ludzie. Umiłowanie sportu znalazło wyraz w niemalże całym pontyfikacie Jana Pawła II. Był pierwszym papieżem w historii Kościoła, który zasiadł na stadionie olimpijskim w Rzymie w roli kibica piłkarskiego. Na audiencjach prywatnych i oficjalnych przyjął setki delegacji organizacji sportowych, klubów piłkarskich, obecnych i byłych zawodników oraz członków ich rodzin. Według Jana Pawła II, sport ujawnia nie tylko siły fizyczne sportowca, ale także zdolności duchowe i intelektualne. Sport - zdaniem papieża - powinien posiadać duszę, aby w ten sposób mieć na celu integralny rozwój człowieka oraz wspomagać proces budowania coraz bardziej ludzkiego społeczeństwa ${ }^{44}$. W czasie Mszy św. na stadionie olimpijskim w Rzymie w Roku Jubileuszowym Jan Paweł II, dokonując „rachunku sumienia dla sportu”, podkreślił, iż sport posiada ogromnie ważne znaczenie dla młodzieży, u której może kształtować ważne dla rozwoju i wychowania wartości, takie jak: lojalność, wytrwałość, przyjaźń, wspólnota. Dlatego też na sportowcach i ludziach zaangażowanych w sport spoczywa ogromna odpowiedzialność, gdyż są oni powołani, aby czynić sport terenem spotkania i dialogu, aby w ten sposób wnosić cenny wkład w pokojowe porozumienie miedzy narodami oraz przyczyniać się do utrwalenia w świecie nowej cywilizacji miłości. Papież zachęca również, aby dla obrony widocznego potencjału wychowawczego i duchowego sportu wierzący i ludzie dobrej woli zjednoczyli siły w walce z wszelkimi wypaczeniami i dewiacjami, jakie mogą zakraść się w sport. Poprzez właściwe wychowanie jednostki i przekazanie jej odpowiedniej hierarchii wartości sport może przyczynić się do wywyższenia człowieka. Musi jednak w tym celu zachować należne miejsce w życiu osobistym, rodzinnym i społecznym, tak aby nie doprowadzić do zaniedbania innych dróg prowadzących do rozwijania wartości ciała, ducha i serca ${ }^{45}$.

${ }^{43}$ J. Niewęgłowski, Wychowawcze wymiary sportu, w: Z. Dziubiński (red.), Drogi, s. 394 -395; por. J. B. Szlaga, Wychowanie przez sport jako wspótczesna forma ewangelizacji młodych, w: Z. Dziubiński (red.), Aksjologia, s. 123.

${ }^{44}$ J. Niewegłowski, Kultura, religia, sport: wspótzależności, w: Z. Dziubiński (red.), Sport jako, s. 141-142; Z. Dziubiński, Jana Pawła II filozofia i teologia sportu, w: tenże (red.), Społeczny wymiar sportu, Warszawa 2003, s. 82-93.

${ }^{45}$ Jan Paweł II, dz. cyt., s. 19-22. 
Jan Paweł II wielokrotnie w swoim nauczaniu dokonywał teologicznej rehabilitacji i nobilitacji sportu, nadając mu sens teologiczny. Pozwala on patrzeć i oceniać go w perspektywie najwyższych wartości chrześcijańskich, dlatego sportowcy powinni „zmierzać ku najwyższym celom”, do których „wzywają igrzyska życia" ${ }^{46}$.

Wyakcentowane powyżej uzasadnienia wartości sportu w nauczaniu Kościoła katolickiego przekonują o jego roli i znaczeniu w całokształcie procesu ewangelizacji. Sport właściwie rozumiany i traktowany jest bowiem nośnikiem wielu takich wartości, dzięki którym może dokonywać się ewangelizacja we współczesnym świecie.

Środowiskiem, w którym z powodzeniem można wykorzystać sport jako narzędzie ewangelizacji, jest parafia. Dyrektorium Katechetyczne Kościoła Katolickiego w Polsce wydane w 2001 roku dowartościowuje parafię jako pierwszoplanowe miejsce katechezy (PDK 106), czyli również procesu ewangelizacji, w którym katecheza uczestniczy. W rozdziale zatytułowanym „Duszpasterstwo katechetyczne w parafii" Dyrektorium podkreśla znaczenie grup, ruchów i stowarzyszeń religijnych działających przy parafii, „o które powinno się szczególnie zabiegać, otaczając je życzliwą opieką duszpasterską" (PDK 111). H. Wrońska, podejmując zagadnienie grup jako środowisk katechetyczno-wychowawczych, zauważa, że duże znaczenie wychowawcze posiadają grupy sportowe. Pomagają one dotrzeć do tych katechizowanych, którzy sprawiają trudności wychowawcze. Wspólne treningi nie tylko sprawiają uczestnikom radość i przyjemność, ale przede wszystkim uczą mobilizacji do pokonywania trudności oraz wytrwałości, która stanowi klucz do osiagnięcia sukcesu. Uprawianie sportu niesie potrzebę przyjęcia ascezy i traktowania jej jako czynnika konstruktywnego i wyzwalającego dla rozwoju osoby ludzkiej. Właściwy postęp w sporcie dokonuje się dzięki przestrzeganiu niezbędnych reguł. Reguła zaś jest podstawą w wychowaniu oraz podstawą sukcesu ${ }^{47}$.

Doskonała propozycją wykorzystania sportu w ewangelizacji wydaje się wciąż aktualny system prewencyjny św. Jana Bosko. Koncepcja wychowawcza św. Jana Bosko uwzględnia współistnienie wielu wartości, zarówno z dziedziny kultury, jak i religii. Ich wzajemne przyporządkowanie oraz przenikanie się jest możliwe dzięki takiej wizji wychowanka, który postrzegany jest jako podmiot otwarty na świat wartości ${ }^{48}$.

Ksiądz Jan Bosko ,jest własnością Kościoła, dlatego ani jego system pedagogiczny, ani refleksja nad tym systemem nie mogą być zarezerwowane wyłącznie

${ }^{46}$ Z. Dziubiński, Kościót rzymskokatolicki a kultura fizyczna, w: tenże (red.), Drogi, s. 148.

${ }^{47}$ H. Wrońska, Katecheza a mate grupy szkolne i parafialne, Lublin 2007, s. 157-158.

${ }^{48} \mathrm{~K}$. Misiaszek, Wychowawcza rola sportu w systemie prewencyjnym św. Jana Bosko, w: Z. Dziubiński (red.), Wychowanie przez sport, Warszawa 1993, s. 53. 
dla salezjanów"49. To zdanie wręcz prowokuje do wykorzystywania systemu prewencyjnego w każdym środowisku parafialnym. W systemie wychowawczym św. Jana Bosko centralne miejsce zajmuje oratorium, czyli miejsce spotkań dla młodzieży.

Stanowi bowiem środowisko, w którym skutecznie rozwija się wspólnota kościelna, nawiązuje głęboki kontakt z ludźmi młodymi, będącymi przyszłością Kościoła, nadającymi mu charakter dynamiczny i twórczy. W swoim wymiarze pastoralnym zmierza do tego, aby odpowiedzieć na wymagania i potrzeby wychowania chrześcijańskiego w konkretnym czasie i określonej rzeczywistości. Podstawowym zaś problemem ludzi młodych jest bezpośredni kontakt z Chrystusem, pogłębiający się na różnych stopniach rozwoju i obejmujący tak osobę, jak i grupę ${ }^{50}$.

Celem głównym oratorium jest integralny rozwój młodego człowieka, aby był dobrym chrześcijaninem i uczciwym obywatelem oraz aby odkrył swoje miejsce w życiu i Kościele. Przy pomocy oratorium ewangelizujemy wychowując i wychowujemy ewangelizując (por. DOK 147) ${ }^{51}$.

Pozamykane domy parafialne, salki katechetyczne bez problemu mogą pełnić rolę oratorium, czyli miejsca spotkań dla dzieci i młodzieży. Wokół budynków parafialnych często istnieją również miejsca, z których można zrobić boiska do uprawiania różnego rodzaju dyscyplin sportowych. Sport, który jest obecny w oratorium, kształci siłę woli, tężyznę fizyczną, uczy zdrowej rywalizacji, ma istotny wpływ na integralny rozwój osobowości. Naczelnym zadaniem oratorium jest tworzenie takich warunków, dzięki którym następuje prawidłowy rozwój religijny i rozwój wiary wychowanka. K. Misiaszek, analizując założenia wychowawcze ks. Bosko, dochodzi do wniosku, że oratoria działające przy parafiach ,powinny tak formułować swój program wychowawczy, aby wyrażał on w sposób jasny i precyzyjny, że celem ludzkiego życia na ziemi jest dążenie do doskonałości; a one (oratoria) mają pomagać w zaspokajaniu tych dążeń" W czasach, kiedy bardzo często duszpasterze narzekają na fakt, iż powrót religii do szkół spowodował odcięcie młodzieży od parafii, system prewencyjny wraz z oratorium wydaje się swoistego rodzaju znakiem czasu, dzięki któremu będzie można na nowo przyciagnąć młodzież do parafii i pomóc jej odnaleźć swoje miejsce w Kościele. Skutecznym narzędziem może okazać się sport.

${ }^{49} \mathrm{~S}$. Semik, Duch rodzinny istotnq wartościq systemu prewencyjnego, w: M. Majewski (red.), Wychowanie chrześcijańskie w duchu św. Jana Bosko, Kraków 1988, s. 135.

${ }^{50} \mathrm{~K}$. Misiaszek, Młodzież w centrum pastoralnej troski salezjanów: oratoryjna propozycja pracy z młodzieża dla Kościoła w Polsce, „Seminare” 12 (1996), s. 205; por. J. Marszałek, Fascynacja sportem inspiracjq autoedukacji w systemie profilaktycznym Księdza Jana Bosko, w: Z. Dziubiński (red.), Sport na przełomie tysiacleci, s. 255-264; J. Niewęgłowski, Rola sportu w systemie prewencyjnym świętego Jana Bosko, w: Z. Dziubiński (red.), Wiara a sport, s. 274-283.

${ }^{51}$ K. Misiaszek, Młodzież, s. 205.

${ }^{52}$ Tamże, s. 206. 


\section{Podsumowanie}

Edukacja współczesnego człowieka poprzez sport wydaje się zadaniem tak samo ważnym, jak i skomplikowanym. Powyższe treści wykazały, iż na ten proces nakłada się wiele elementów i zjawisk, które w końcowym rachunku tworzą pewną wypadkową procesu edukacyjnego. Edukacja zawsze powinna mieć charakter perspektywiczny, w którym newralgicznym punktem odniesienia jest odpowiedzialnie zdefiniowane dobro człowieka. Wartość człowieka jako człowieka nie powinna podlegać tu żadnym spekulacjom i stanowi ważny fundament, na którym buduje się wychowanie każdego człowieka. Sport właściwie rozumiany i interpretowany może być niewątpliwie znaczącą częścią określonego modelu edukacyjnego i partycypować w rozwoju człowieczeństwa.

Wydobycie ze zjawiska sportu wartości istotnych i niepodważalnych zawsze winno dokonywać się w optyce etyczno-moralnej, gdyż to pozwala nie tylko na uchwycenie tego, co autentycznie dobre w sporcie, ale również na wykazanie dewiacji i nadużyć. Normy etyczne i moralne w sporcie stoją niejako na straży jego niezaprzeczalnej wartości edukacyjnej. Wychowanie do zwycięstwa, porażki, bezinteresowności, zasady fair play oraz możliwość kształtowania cnót kardynalnych, takich jak: roztropność, sprawiedliwość, męstwo i umiarkowanie, to tylko niektóre ważne elementy procesu edukacyjnego człowieka, które można rozwijać dzięki posługiwaniu się narzędziem sportu.

Wartość sportu w procesie ewangelizacji była niejednokrotnie podkreślana w całej historii Kościoła. Już w Biblii i u Ojców Kościoła spotykamy posługiwanie się tzw. „ewangelizacyjnymi obrazami” zaczerpniętymi ze sportu, aby w ten sposób przekonywać ludzi do Ewangelii. Ogromy wpływ na dowartościowanie sportu poprzez osobiste jego umiłowanie i liczne wypowiedzi wywarł papież Jan Paweł II. Często podkreślał, że sport jest dzisiaj ważnym narzędziem integralnego rozwoju człowieka i budowania społeczeństwa bardziej ludzkiego oraz formą ewangelizacji. Środowisko parafialne w warunkach polskiej katechezy szkolnej jawi się jako miejsce, gdzie z powodzeniem można posługiwać się sportem jako narzędziem ewangelizacji. Doskonałą ku temu możliwość stwarza zaczerpnięte z wychowawczego systemu prewencyjnego św. Jana Bosko oratorium, miejsce spotkań dla młodzieży przy parafii. Wykorzystanie przyparafialnych domów i salek katechetycznych na oratoria może okazać się dobrym pomysłem przyciągnięcia dzieci i młodzieży do Kościoła i ewangelizowania ich także za pomoca wszechobecnego dziś sportu.

Sport to niezaprzeczalny fenomen kulturowy naszych czasów, obejmujący swym zasięgiem wszystkie kontynenty i narody świata. Od księży, wychowawców, nauczycieli, katechetów, animatorów sportu w dużej mierze zależy, czy sport będzie skutecznym narzędziem wykorzystywanym w procesie wychowania i ewangelizacji współczesnego człowieka. 


\section{Sport in education and evangelization (Summary)}

Contemporary sport is one of the biggest cultural phenomenon of the $20^{\text {th }}$ and $21^{\text {st }}$ century covering all the continents and nations. Huge amounts of money and milliards of fans are involved in it. Sport is undeniably one of the most popular and most important disciplines of human life. From the very beginning people have been improving the reality they live in, also as far as sport is concerned. Thanks to the fact that nowadays media are better and more accessible it has become a wide-spread occurrence. For contemporary societies sports events are very significant. When it is based on humanistic foundations and on the Olimpic ideals of ancient Greece, where sport was an integral part of education, it can significantly influence the formation of a man's personality. Unfortunately, degradation of sport through corruption, doping or disorderly behaviour of fans can also be observed.

That is why it is crucial to constantly remind of the proper interpretation of sport and its place in human's life and consequently its role in the process of education and evangelization. At first, to present the topic of sport in the right way the phenomenon of it is defined. Then sport is shown in the context of ethical and moral evaluation and its advantages and disadvantages are presented. Afterwards, some possibilities of using sport in the process of education are demonstrated. After that, sport is depicted as a contemporary form of evangelization in the parish. 